\title{
Free Radical Scavenging Activities of Date Palm (Phoenix sylvestris) Fruit Extracts
}

Kaustab Mukherjee, Pramathadhip Paul and Ena Ray Banerjee ${ }^{1 *}$

Department of Zoology, Immunology and Regenerative Medicine Research Laboratory, University of Calcutta, India

\begin{abstract}
Fruit of date palm (Phoenix sylvestris L.) is edible and used as an anti-geriatric, anti-oxidant ethnomedicine. In this study, three different types of date palm extracts, methanolic, acidic ethanolic and basic ethanolic were evaluated for their putative in vitro scavenging effects on reactive oxygen species (ROS) where scavenging of hydroxyl radicals (basic ethanolic>acidic ethanolic >methanolic), superoxide radicals (acidic ethanolic $>$ basic ethanolic $>$ methanolic), DPPH radical (acidic ethanolic>methanolic >basic ethanolic), [nitric oxide (NO)] (methanolic >acidic ethanolic >basic ethanolic) and inhibition of lipid peroxidation (basic ethanolic>acidic ethanolic > methanolic) were found to occur in a dose dependent manner. Their flavonoid and phenolic contents proved to be the source of this potent scavenging activity and showed a direct correlation with their total anti-oxidant capacity. On human embryonic kidney cell line (HEK) and murine RAW macrophages, bacterial lipopolysaccharide (LPS) induced inflammation, the date palm extracts applied therapeutically, inhibit intracellular oxidative stress significantly. This reinstatement of cellular homeostasis presumably occurs via mitochondrial pathways.
\end{abstract}

Keywords: Inflammation; Anti-oxidant; Phenolic compounds; Scavenger activities; Reactive oxygen nitrogen intermediates

\section{Introduction}

Inflammation, either acute or chronic, is the body's response to disturbed homeostasis caused by infection, injury or trauma resulting in systemic and local effects. Inflammatory response occurs in three distinct phases [1]. The first phase is caused by an increase in vascular permeability resulting in exudation of fluids from the blood into the interstitial space, the second phase involves the infiltration of leukocytes from blood into tissue space and in third phase granuloma formation and tissue repair occurs.

Inflammation is the key driving force for most disorders. A delicate balance between beneficial effects of inflammation cascades and their apparently destructive mechanism is key to the body's homeostasis and it is the breakdown of such balance through regulatory disruption that lead to the clinical manifestation of diseases such as asthma, rheumatoid arthritis, psoriasis, multiple sclerosis, obesity and inflammatory bowel disease [2]. Though the specific characteristic features of inflammatory response in each disease and the site of their occurrence may vary, a universal feature governing this phenomenon is the complex interplay amongst the many different inflammatory cell types, recruitment and activation of inflammatory cells such as neutrophils, eosinophils and macrophages and changes in the structural cells with a concomitant increase in the expression of components of inflammatory cascade including cytokines, chemokines, growth factors, enzymes, receptors, adhesion molecules and other biochemical mediators, affecting various target tissues [2,3].

Despite the advances in medical technology and hygiene, the introduction of vaccines and modern medications, and intense ongoing research, the prevalence of inflammatory disorders has continued to increase in the last few decades throughout the globe [4]. Although the best approach to investigate various inflammatory processes, and to identify crucial pathways and potential novel targets for drug therapy, is to perform studies in human patients, due to ethical reasons these are not always possible necessitating the development of various preclinical animal models and cell lines, both human and non-human, to elucidate the pathophysiology of various inflammatory disorders, and to identify and evaluate novel therapeutic targets for them. The utility of these models, both in vitro and in vivo, to understand the mechanistic phenomenon operative in a human disease and to develop therapeutics, is the topic of considerable debate due to the non-availability of any completely accepted model for the human disease. Preclinical disease models need to be carefully selected if they are to be predictive of the biology, expected in treating human disease. Consideration of the particular biology reflected in the model, as well as whether the qualities of the potential therapeutic (or its species-specific surrogate molecule) will be represented adequately in a non-human species, so that the drug discovery and development industry will continue to make progress in predicting potential therapeutic efficacy and benefit of new drugs in patients for the successful drug development.

From the ancient period the role of traditional medicines in the solution of health problems is invaluable on a global level. In traditional medicine medicinal plants continue to provide valuable therapeutic agents. Due to various side effects and complications of the modern medicine, and to address unmet needs of the particular disease, specially complex etio-pathophysiological pathways traditional medicine is gaining importance and is now being studied systematically and using biotechnological tools, to find the scientific basis of their therapeutic actions.

Phytochemicals from fruits and other edible plant parts have been shown to possess significant antioxidant properties that may be associated with lower incidence and lower mortality rates of degenerative diseases in human. Different biological properties, antioxidant capacities and radical-scavenging activities of various herbal extracts have been widely demonstrated, using in vitro techniques and in vivo models by different groups of researchers [5-7]. The anti-proliferative and anti-inflammatory activities of these herbal

*Corresponding author: Ena Ray Banerjee, Department of Zoology, Immunology and Regenerative Medicine Research Laboratory, University of Calcutta, 35, Ballygunge Circular Road, Kolkata- 700019, West Bengal, India, Tel: 91-33-24615445 (Extn.275); Fax: 91-33-24614849; E-mail: enarb1@gmail.com

Received September 23, 2014; Accepted October 09, 2014; Published October 11,2014

Citation: Mukherjee K, Paul P, Banerjee ER (2014) Free Radical Scavenging Activities of Date Palm (Phoenix sylvestris) Fruit Extracts. Nat Prod Chem Res 2: 151. doi:10.4172/2329-6836.1000151

Copyright: (c) 2014 Mukherjee K, et al. This is an open-access article distributed under the terms of the Creative Commons Attribution License, which permits unrestricted use, distribution, and reproduction in any medium, provided the original author and source are credited. 
extracts have been documented in human oral, breast, colon, cervical, and prostate cancer cell lines as well as preclinical animal models by attenuating some inflammation intermediates, including nitric oxide, NF-kB, and TNFa $[8,9]$.

The aim of our study was to first detect potential anti-inflammatory activities of various extracts from a fruit that is traditionally known as an anti-geriatric compound. High content of various phenolic and non-phenolic compounds and other uncharacterized moieties may contribute to its use not only as a highly nutritive edible plant part but also position it as a nutraceutical substance and a prophylactic cum therapeutic compound in oxidative inflammatory diseases. Comparison of antioxidant and anti-inflammatory activities of date palm extracted by three distinct methods viz. methanolic extracts, basic ethanolic extracts and acidic ethanolic extracts have been assessed along with evaluation of their anti-oxidative / anti-inflammatory capacities.

\section{Materials and Methods}

\section{Reagents}

Chemicals, such as ethylenediamine tetra acetic acid (EDTA), trichloroacetic acid (TCA), butanol, ammonium molybdate, and sodium dodecyl sulphate, benzoic acid, sodium phosphate, DMSO were purchased from E. Merck (India) Limited. 1,1 Diphenyl-2-picrylhydrazyl and Malondialdehyde, Potassium ferricyanite, thiobarbituric acid (TBA) were procured from Sigma, USA. N-butanol, Ferus sulphate, Ferric chloride, Folins reagent, Riboflavin, naphthylethylenediamine dihydrochloride, and sulphanilamide in phosphoric acid, Sodium bicarbonate, Sodium hydroxide, and potassium hydroxide were purchased from Sisco Research Laboratories PVT. Ltd India. Nitroblue tetrazolium, were purchased from Himedia, India. All other reagents were of analytical grade.

\section{DPPH radical-scavenging activity}

The antioxidant activity of the extracts was measured on the basis of the scavenging activity of the stable 1,1-diphenyl-2-picrylhydrazyl $(\mathrm{DPPH})$ free radical [10]. Aqueous extract was added to a $0.004 \%$ Methanol solution of DPPH on a 96 well ELISA plate. Absorbance at $517 \mathrm{~nm}$ was determined after $30 \mathrm{~min}$, and the percent inhibition activity was calculated.

\section{Assay of superoxide radical $\mathrm{O}_{2}{ }^{\circ}{ }^{\circ}$ scavenging activity}

The method used by Martinez et al. [11] for determination of the superoxide dismutase was studied in the riboflavin-lightnitrobluetetrazolium (NBT) system [12]. Each $0.1 \mathrm{ml}$ of reaction mixture contained $50 \mathrm{mM}$ phosphate buffer ( $\mathrm{pH} 7.8), 13 \mathrm{mM}$ methionine, $21 \mathrm{M}$ riboflavin, $100 \mu \mathrm{M}$ EDTA, NBT $(75 \mu \mathrm{M})$ and various doses of sample solution. The production of blue formazan was followed by monitoring the increase in absorbance at $560 \mathrm{~nm}$ after $15 \mathrm{~min}$ of illumination from a fluorescent lamp.

\section{Assay of hydroxyl radical (-OH)-scavenging activity}

The assay was based on the benzoic acid hydroxylation method [13]. Hydroxyl radicals were generated by direct addition of iron (II) salts to a reaction mixture containing phosphate buffer. In a 24 well plate, $0.15 \mathrm{ml}$ of sodium benzoate $(10 \mathrm{mM})$ and $0.15 \mathrm{ml}$ of $\mathrm{FeSO}_{4}, 7 \mathrm{H}_{2} \mathrm{O}(10$ $\mathrm{mM})$ and EDTA $(10 \mathrm{mM})$ were added. Then the sample solution and a phosphate buffer $(\mathrm{pH} 7.4,0.1 \mathrm{M})$ were added to give a total volume of $1.6 \mathrm{ml}$. Finally, $0.15 \mathrm{ml}$ of an $\mathrm{H}_{2} \mathrm{O}_{2}$ solution $(10 \mathrm{mM})$ was added. The reaction mixture was then incubated at $37^{\circ} \mathrm{C}$ for $2 \mathrm{~h}$. After that, the fluorescence was measured at $407 \mathrm{~nm}$ emission (Em) and excitation (Ex) at $305 \mathrm{~nm}$. Measurement of spectrofluorometric changes has been used to detect the damage by the hydroxyl radical.

\section{Lipid peroxidation assay}

A modified thiobarbituric acid reactive species (TBARS) assay was used to measure the lipid peroxide formed using egg yolk homogenates as lipid-rich media [14] where lipid peroxidation was induced by $\mathrm{FeSO}_{4}$ and Malondialdehyde (MDA), produced by the oxidation of polyunsaturated fatty acids, reacts with two molecules of thiobarbituric acid (TBA) yielding a pinkish red chromogen with an absorbance maximum at $532 \mathrm{~nm}$ which was measured using a 96 well ELISA plate. Percentage inhibition of lipid peroxidation by different concentrations of the extract was calculated.

\section{Determination of total antioxidant capacity}

The assay is based on the reduction of $\mathrm{Mo}(\mathrm{VI})$ to $\mathrm{Mo}(\mathrm{V})$ by the extract and subsequent formation of a green phosphate/Mo(V) complex at acid $\mathrm{pH}$ [15]. Each well of a 96 well ELISA plate containing extract and reagent solution $(0.6 \mathrm{M}$ sulfuric acid, $28 \mathrm{mM}$ sodium phosphate and $4 \mathrm{mM}$ ammonium molybdate) were incubated at $95^{\circ} \mathrm{C}$ for $90 \mathrm{~min}$. After the mixture had cooled to room temperature, the absorbance of each solution was measured at $695 \mathrm{~nm}$ against a blank. The antioxidant capacity was expressed as ascorbic acid equivalent (AAE).

\section{Determination of total flavonoid content}

Total flavonoid content was determined using aluminium chloride $\left(\mathrm{AlCl}_{3}\right)$ according to a known method, 15 using Fisetin as a standard. The date palm extract $(0.1 \mathrm{ml})$ were added to $0.3 \mathrm{ml}$ distilled water followed by $5 \% \mathrm{NaNO}_{2}(0.03 \mathrm{ml})$. After $5 \mathrm{~min}$ at $25^{\circ} \mathrm{C}, \mathrm{AlCl}_{3}(0.03 \mathrm{ml}$, $10 \%)$ was added. After further $5 \mathrm{~min}$, the reaction mixture was treated with $0.2 \mathrm{ml}$ of $1 \mathrm{mM} \mathrm{NaOH}$. Finally, the reaction mixture was diluted to $1 \mathrm{ml}$ with water and the absorbance was measured at $510 \mathrm{~nm}$. The results were expressed as $\mathrm{mg}$ Fisetin/g date palm extract.

\section{Determination of total phenolic content}

The total phenolic content of the date palm extracts extracts was determined using the Folin-Ciocalteu reagent. The reaction mixture contained: $200 \mu \mathrm{l}$ of diluted extract, $800 \mu \mathrm{l}$ of freshly prepared diluted Folin Ciocalteu reagent and $2 \mathrm{ml}$ of $7.5 \%$ sodium carbonate. The final mixture was diluted to $7 \mathrm{ml}$ with deionized water. Mixtures were kept in dark at ambient conditions for $2 \mathrm{~h}$ to complete the reaction. The absorbance at $765 \mathrm{~nm}$ was measured. Gallic acid was used as standard and the results were expressed as mg gallic acid (GAE)/g of the date palm extract.

\section{Results and Discussion}

As many as $70 \%$ of all drugs used today for the treatment of degenerative diseases due to inflammatory cascades were derived from or based on natural products. Although fruits and vegetables have been linked with reduction of risk of cancer, cardiovascular diseases, autoimmune diseases, and various other chronic illnesses, neither the active components nor their mechanisms of action are well established. Identification of active ingredients in dietary plants, and the cell signalling pathways they modulate, can validate their use in various diseases.

For a long time it has been known that ROS perform essential roles in immune response to pathogens, including bacterial killing through production of superoxide by reduced nicotinamide adenine dinucleotide phosphate (NADPH) oxidases during respiratory burst in activated macrophages and neutrophils $[16,17]$. This is further corroborated by studies on patients with chronic granulomatous 
disease (CGD) or genetically engineered mice lacking components of the NADPH oxidase enzyme (NOX) $[18,19]$.

Free radicals, formed during normal metabolic process of the body are transient in existence and sometimes trigger further downstream activation pathways where they may behave as second messengers. But produced in unregulated catabolic cycles, are dangerous substances produced in the body along with toxins and wastes and may be a critical driving force in various pathophysiological conditions in humans. They damage and disrupt by altering the normal homeostasis. The last two decades and more it has been deducted to studying these intermediate free radicals and their action on cellular physiology. From these studies, it has been generally established that in various inflammatory diseases, such as rheumatoid arthritis [20] multiple sclerosis [21], and type 1 diabetes [22] reactive oxygen species (ROS) is a pivotal factor engendering tissue degeneration.
In the present study date palm extracts were prepared using three different methods and then their anti-inflammatory activities has been evaluated. Also many other plant species have been investigated in the search for novel antioxidants but generally there is still a demand to find more information concerning the antioxidant potential of plant species. It has been mentioned the antioxidant activity of plants might be due to their phenolic compounds. Flavonoids are a group of poly phenolic compounds with known properties which include free radical scavenging, inhibition of hydrolytic and oxidative enzymes and anti-inflammatory action. Here we have clearly demonstrated that date palm extracts, collected by three different methods hold a potent antioxidative properties by showing DPPH radical scavenging activities (Table 1), hydroxyl radical scavenging (Table 2), superoxide radical scavenging (Table 3), significant inhibition of lipid peroxidation (Table 4). The calculated $\mathrm{IC}_{50}$ values of these three different extracts of

DPPH radical-scavenging activity:

\begin{tabular}{|c|c|c|c|c|}
\hline concentrations & $\begin{array}{c}\text { Methanolic extract } \\
\left(\mathrm{IC}_{50} 22.91 \mu \mathrm{g} / \mathrm{ml}\right) \\
\mathrm{Y}=9.919 x+22.74, \mathrm{r}^{2}=0.909 \\
\% \text { inhibition } \pm \mathrm{SD}(\mathrm{n}=5)\end{array}$ & $\begin{array}{c}\text { Acidic ethanolic extract } \\
\left(\mathrm{IC}_{50} 14.61 \mu \mathrm{g} / \mathrm{ml}\right) \\
\mathrm{Y}=16.65 \mathrm{X}+6.718, \mathrm{r}^{2}=0.933 \\
\% \text { inhibition } \pm \mathrm{SD}(\mathrm{n}=5)\end{array}$ & $\begin{array}{c}\text { Basic ethanolic extract } \\
\left(\mathrm{IC}_{50} 36.44 \mu \mathrm{g} / \mathrm{ml}\right) \\
\mathrm{Y}=6.783 \mathrm{X}+2.773, \mathrm{r}^{2}=0.930 \\
\% \text { inhibition } \pm \mathrm{SD}(\mathrm{n}=5)\end{array}$ & $\begin{array}{c}\text { Ascorbic acid } \\
\left(\mathrm{IC}_{50} 4.82 \mu \mathrm{g} / \mathrm{ml}\right) \\
\mathrm{Y}=15.06 \mathrm{X}+16.62, \mathrm{r}^{2}=0.963 \\
\% \text { inhibition } \pm \mathrm{SD}(\mathrm{n}=5)\end{array}$ \\
\hline $1 \mathrm{mg} / \mathrm{ml}$ & $74.68 \pm 1.66$ & $86.28 \pm 1.82$ & $38.88 \pm 1.20$ & $89.24 \pm 1.25$ \\
\hline $250 \mu \mathrm{g} / \mathrm{ml}$ & $56.69 \pm 1.58$ & $72.26 \pm 1.40$ & $30.15 \pm 1.32$ & $75.46 \pm 1.20$ \\
\hline $100 \mu \mathrm{g} / \mathrm{ml}$ & $53.11 \pm 1.42$ & $61.11 \pm 1.26$ & $19.40 \pm 1.36$ & $70.00 \pm 1.30$ \\
\hline $50 \mu \mathrm{g} / \mathrm{ml}$ & $49.22 \pm 1.39$ & $49.22 \pm 1.02$ & $14.28 \pm 1.28$ & $45.56 \pm 1.30$ \\
\hline $10 \mu \mathrm{g} / \mathrm{ml}$ & $28.82 \pm 1.87$ & $14.53 \pm 0.96$ & $12.90 \pm 2.00$ & $28.86 \pm 1.28$ \\
\hline
\end{tabular}

Table 1: DPPH radical-scavenging activity (DPPH assay shows that, in this system, the radical-scavenging activities of the three date palm extracts are in this order: acidic ethanolic extracts>methanolic extract>basic ethanolic extract).

Various concentrations of date palm extracts, collected by three distinct methods, scavenge hydroxyl radical in a dose-dependent manner $\left[r^{2}=0.832\right.$ ( $\left.p<0.01\right)$ for methanolic

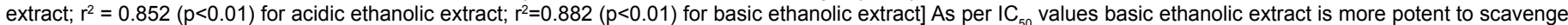
hydroxyl radicals $\left(\mathrm{IC}_{50} 17.00 \mu \mathrm{g} / \mathrm{ml}\right)$ than the acidic ethanolic extracts $\left(\mathrm{IC}_{50} 17.30 \mu \mathrm{g} / \mathrm{ml}\right)$ and methanolic extracts $\left(\mathrm{IC}_{50} 18.20 \mu \mathrm{g} / \mathrm{ml}\right)$.

Hydroxyl radical $(\mathrm{OH})$ scavenging activity:

\begin{tabular}{|c|c|c|c|}
\hline concentrations & $\begin{array}{c}\text { Methanolic Extract }\left(I C_{50} 18.20 \mu \mathrm{g} / \mathrm{ml}\right) \\
Y=13.73 X+0.098, \mathrm{r}^{2}=0.832 \\
\% \text { inhibition } \pm S D(n=5)\end{array}$ & $\begin{array}{c}\text { Acidic ethanolic Extract }\left(\mathrm{IC}_{50} 17.30 \mu \mathrm{g} / \mathrm{ml}\right) \\
Y=11.95 X+43.19, \mathrm{r}^{2}=0.852 \\
\% \text { inhibition } \pm S D(n=5)\end{array}$ & $\begin{array}{c}\text { Basic ethanolic Extract }\left(\mathrm{IC}_{50} 17.00 \mu \mathrm{g} / \mathrm{ml}\right) \\
Y=12.93 X+30.19, \mathrm{r}^{2}=0.882 \\
\% \text { inhibition } \pm S D(n=5)\end{array}$ \\
\hline $1 \mathrm{mg} / \mathrm{ml}$ & $81.01 \pm 0.066$ & $96.84 \pm 0.048$ & $87.49 \pm 0.038$ \\
\hline $250 \mu \mathrm{g} / \mathrm{ml}$ & $41.50 \pm 0.034$ & $90.57 \pm 0.053$ & $84.67 \pm 0.046$ \\
\hline $100 \mu \mathrm{g} / \mathrm{ml}$ & $36.90 \pm 0.058$ & $89.75 \pm 0.054$ & $77.38 \pm 0.076$ \\
\hline $50 \mu \mathrm{g} / \mathrm{ml}$ & $28.08 \pm 0.068$ & $71.70 \pm 0.064$ & $60.64 \pm 0.066$ \\
\hline $10 \mu \mathrm{g} / \mathrm{ml}$ & $19.04 \pm 0.098$ & $46.49 \pm 0,071$ & $34.83 \pm 0.042$ \\
\hline
\end{tabular}

Table 2: Hydroxyl radical $(\mathrm{OH})$ scavenging activity (Hydroxyl radical scavenging assay shows that, in this system, the hydroxyl radical-scavenging activities of the three date palm extracts are in this order: basic ethanolic extracts>acidic ethanolic extract>methanolic extract)

Various concentrations of date palm extracts, collected by three distinct methods, scavenge Superoxide radical in a dose-dependent manner $[r 2=0.809$ ( $<<0.01$ ) for methanolic extract; $r 2=0.908(p<0.01)$ for acidic ethanolic extract; $r 2=0.928(p<0.01)$ for basic ethanolic extract] As per IC50 values acidic ethanolic extract is more potent to superoxide radicals (IC50 $19.00 \mu \mathrm{g} / \mathrm{ml}$ ) than the basic ethanolic extracts (IC50 $19.15 \mu \mathrm{g} / \mathrm{ml}$ ) and methanolic extracts (IC50 $28.88 \mu \mathrm{g} / \mathrm{ml}$ ).

Superoxide radical scavenging assay:

\begin{tabular}{|c|c|c|c|}
\hline concentrations & $\begin{array}{c}\text { Methanolic Extract }\left(\mathrm{IC}_{50} 28.88 \mu \mathrm{g} / \mathrm{ml}\right) \\
\mathrm{Y}=8.66 X-0.16, \mathrm{r}^{2}=0.809 \\
\% \text { inhibition } \pm \mathrm{SD}(\mathrm{n}=5)\end{array}$ & $\begin{array}{c}\text { Acidic Ethanolic extract }\left(\mathrm{IC}_{50} 19.00 \mu \mathrm{g} / \mathrm{ml}\right) \\
Y=13.36 X-3.936, \mathrm{r}^{2}=0.908 \\
\% \text { inhibition } \pm \text { SD }(n=5)\end{array}$ & $\begin{array}{c}\text { Basic Ethanolic extract }\left(\mathrm{IC}_{50} 19.15 \mu \mathrm{g} / \mathrm{ml}\right) \\
Y=13.40 X-6.724, \mathrm{r}^{2}=0.928 \\
\% \text { inhibition } \pm \mathrm{SD}(\mathrm{n}=5)\end{array}$ \\
\hline $1 \mathrm{mg} / \mathrm{ml}$ & $51.5 \pm 0.011$ & $65.60 \pm 0.114$ & $58.90 \pm 0.025$ \\
\hline $250 \mu \mathrm{g} / \mathrm{ml}$ & $25.60 \pm 0.015$ & $53.80 \pm 0.017$ & $54.60 \pm 0.028$ \\
\hline $100 \mu \mathrm{g} / \mathrm{ml}$ & $22.80 \pm 0.004$ & $25.58 \pm 0.011$ & $26.12 \pm 0.0053$ \\
\hline $50 \mu \mathrm{g} / \mathrm{ml}$ & $16.40 \pm 0.003$ & $20.40 \pm 0.005$ & $17.28 \pm 0.0009$ \\
\hline $10 \mu \mathrm{g} / \mathrm{ml}$ & $12.80 \pm 0.004$ & $15.46 \pm 0.007$ & $10.54 \pm 0.0017$ \\
\hline
\end{tabular}

Table 3: Superoxide radical $\mathrm{O}_{2}-^{\circ}$ scavenging activity (Superoxide radical scavenging assay shows that, in this system, the superoxide radical-scavenging activities of the three date palm extracts are in this order : acidic ethanolic extracts>basic ethanolic extract>methanolic extract)

Various concentrations of date palm extracts, collected by three distinct methods, scavenge Superoxide radical in a dose-dependent manner $[r 2=0.809$ ( $p<0.01$ ) for methanolic extract; $r 2=0.908(p<0.01)$ for acidic ethanolic extract; $r 2=0.928(p<0.01)$ for basic ethanolic extract] As per IC50 values acidic ethanolic extract is more potent to superoxide radicals (IC50 $19.00 \mu \mathrm{g} / \mathrm{ml}$ ) than the basic ethanolic extracts (IC50 $19.15 \mu \mathrm{g} / \mathrm{ml}$ ) and methanolic extracts (IC50 $28.88 \mu \mathrm{g} / \mathrm{ml}$ ). 
date palm advocated the strong antioxidative properties of these crude extracts (Table 5)

\section{DPPH radical-scavenging activity}

Reactive oxygen species (ROS) cause oxidative modifications to DNA, proteins, lipids, and small intracellular molecules. Lipids, including pulmonary surfactants, react with ROS to produce lipid peroxides, which cause increased membrane permeability and inactivation of surfactants [23]. In turn, reaction of ROS with cellular proteins leads to decreased protein synthesis due to the modification of proteins involved in translation and translocation, ultimately resulting in impaired cellular metabolism. The oxidative stress induced by the overproduction of ROS has been associated with many clinical conditions including cancer, asthma, cystic fibrosis, ischemiareperfusion injury, drug-induced toxicity and aging.

Antioxidants, on interaction with DPPH transfer an electron (hydrogen atom) to $\mathrm{DPPH}$, neutralizing its free radical character [24]. The colour changes from purple to yellow and its absorbance at wavelength 517 decreases. Various concentrations of date palm extracts, collected by three distinct methods, quenched DPPH free radical in a dose-dependent manner $\left[\mathrm{r}^{2}=0.909(\mathrm{p}<0.05)\right.$ for methanolic extract; $\mathrm{r}^{2}=$ $0.933(\mathrm{p}<0.05)$ for acidic ethanolic extract; $\mathrm{r}^{2}=0.930(\mathrm{p}<0.05)$ for basic ethanolic extract]. $\mathrm{IC}_{50}$ values were $22.91 \mu \mathrm{g} / \mathrm{ml}$ for methanolic extract, $14.61 \mu \mathrm{g} / \mathrm{ml}$ for acidic ethanolic extract and $36.44 \mu \mathrm{g} / \mathrm{ml}$ for basic ethanolic extract. DPPH assay shows that, in this system, the radicalscavenging activities of the three varieties of date palm extracts are in the order acidic ethanolic extract $>$ methanolic extract $>$ basic ethanolic extract.

\section{Assay of hydroxyl radical $(\mathrm{OH})$-scavenging activity}

By the addition of iron (II) salts to a phosphate buffer containing reaction mixture, Hydroxyl radicals can be generated [25]. Benzoate, weakly fluorescent, after monohydroxylation forms highly fluorescent hydroxybenzoates [26]. Measurement of this spectrofluorometric changes has been used to detect damage by hydroxyl radical. Date palm extracts collected by three distinctly separate methods was found to be a powerful scavenger of hydroxyl radicals. There is a linear correlation between concentration of extract and ${ }^{\circ} \mathrm{OH}$-scavenging activity $\left[\mathrm{r}^{2}=0.832(\mathrm{p}<0.05)\right.$ for methanolic extracts of date palm; $\mathrm{r}^{2}$ $=0.8352(p<0.05)$ for acidic ethanolic extracts of date palm; $r^{2}=0.882$ $(\mathrm{p}<0.05)$ for basic ethanolic extracts of date palm]. $\mathrm{IC}_{50}$ values are $18.20 \mu \mathrm{g} / \mathrm{ml}$ for methanolic date palm extracts, $17.30 \mu \mathrm{g} / \mathrm{ml}$ for acidic ethanolic date palm extracts and $17.00 \mu \mathrm{g} / \mathrm{ml}$ for basic ethanolic extrcts. Highest hydroxyl radical-scavenging activity was found in the date palm extract collected by using basic ethanolic methods. The hydroxyl radical scavenging properties of date palm extracts are: basic ethanolic extracts $>$ acidic ethanolic extracts $>$ methanolic extracts.

\section{Assay of superoxide radical $\mathrm{O}_{2}{ }^{\circ}$ scavenging activity}

Photochemical reduction of flavins generates $\mathrm{O}_{2}$ which reduces NBT, resulting in the formation of blue formazan [12]. Three types of date palm extracts inhibited the formation of the blue formazan and $\%$ inhibition is proportional to the concentration $\left[\mathrm{r}^{2}==0.870(\mathrm{p}<0.05)\right.$ for methanolic extract; $\mathrm{r}^{2}=0.908(\mathrm{p}<0.05)$ for acidic ethanolic extract; $\mathrm{r}^{2}=0.928(\mathrm{p}<0.05)$ for basic ethanolic extract]. $\mathrm{IC}_{50}$ values were 28.88 $\mu \mathrm{g} / \mathrm{ml}$ for methanolic extract, $19.00 \mu \mathrm{g} / \mathrm{ml}$ for acidic ethanolic extract and 19.15 for acidic ethanolic extract. The superoxide ion scavenging activities of all these three extracts are: acidic ethanolic extract $>$ basic ethanolic extract $>$ methanolic extracts.

\section{Lipid peroxidation assay}

Egg yolk lipids undergo rapid non-enzymatic peroxidation when incubated in the presence of ferrous sulphate. Lipid peroxides are likely involved in numerous pathological events, including inflammation, metabolic disorders and cellular aging [27,28]. Date palm extracts inhibited lipid peroxidation in a concentration-dependent manner $\left[\mathrm{r}^{2}\right.$ $=0.870(p<0.05)$ for methanolic extract; $r^{2}=0.635(p<0.05)$ for acidic

Lipid peroxidation inhibition assay:

\begin{tabular}{|c|c|c|c|}
\hline concentrations & $\begin{array}{c}\text { Methanolic extract }\left(I C_{50} 60.69\right) \\
Y=4.02 X+5.618, r^{2}=0.870 \\
\% \text { of inhibition } \pm \text { SD }(n=5)\end{array}$ & $\begin{array}{c}\text { Acidic ethanolic extract }\left(I_{50^{\circ}} \text { 24.75) }\right. \\
Y=10.22 X-3.023, r^{2}=0.635 \\
\% \text { of inhibition } \pm S D(n=5)\end{array}$ & $\begin{array}{c}\text { Basic ethanolic extract }\left(I_{50} 18.03\right) \\
Y=13.28 X+10.56, r^{2}=0.978 \\
\% \text { of inhibition } \pm S D(n=5)\end{array}$ \\
\hline $1 \mathrm{mg} / \mathrm{ml}$ & $28.68 \pm 1.62$ & $63.60 \pm 2.68$ & $80.28 \pm 2.99$ \\
\hline $250 \mu \mathrm{g} / \mathrm{ml}$ & $19.50 \pm 1.53$ & $22.9 \pm 1.28$ & $61.50 \pm 2.90$ \\
\hline $100 \mu \mathrm{g} / \mathrm{ml}$ & $14.9 \pm 1.42$ & $19.5 \pm 1.02$ & $48.44 \pm 1.20$ \\
\hline $50 \mu \mathrm{g} / \mathrm{ml}$ & $14.2 \pm 0.68$ & $16.75 \pm 2.10$ & $34.56 \pm 1.08$ \\
\hline $10 \mu \mathrm{g} / \mathrm{ml}$ & $11.2 \pm 0.89$ & $15.54 \pm 1.04$ & $27.32 \pm 0.92$ \\
\hline
\end{tabular}

Table 4: Lipid peroxidation inhibition assay (Lipid peroxidation assay shows that, in this system, to prevent the lipid peroxidation, the three date palm extracts are in this order : basic ethanolic extract>acidic ethanolic extract $>$ methanolic extracts)

Various concentrations of date palm extracts, collected by three distinct methods, inhibit lipid peroxidation, using egg yolk homogenate as a substrate, in a dose-dependent manner $\left[r^{2}=0.870(p<0.01)\right.$ for methanolic extract; $r^{2}=0.635(p<0.01)$ for acidic ethanolic extract; $r^{2}=0.978(p<0.01)$ for basic ethanolic extract] As per IC ${ }_{50}$ values basic ethanolic date palm extract is more potent to inhibit the lipid peroxidation $\left(\mathrm{IC}_{50} 18.03 \mu \mathrm{g} / \mathrm{ml}\right.$ ) than the acidic ethanolic extracts $\left(\mathrm{IC}_{50} 24.75 \mu \mathrm{g} / \mathrm{ml}\right)$ and methanolic date pam extracts $\left(\mathrm{IC}_{50} 60.69 \mu \mathrm{g} / \mathrm{ml}\right)$.

Total antioxidant capacity:

\begin{tabular}{|c|c|c|c|}
\hline concentrations & $\begin{array}{c}\text { Methanolic extract } \\
\text { (equivalent to ASA/mg of plant material) (n=5) }\end{array}$ & $\begin{array}{c}\text { Acidic ethanolic extract } \\
\text { (equivalent to ASA/mg of plant material) }\end{array}$ (n=5) & $\begin{array}{c}\text { Basic ethanolic extract } \\
\text { (equivalent to ASA/mg of plant material) (n=5) }\end{array}$ \\
\hline $1 \mathrm{mg} / \mathrm{ml}$ & $104.67 \pm 1.224$ & $382.154 \pm 2.20$ & $282.18 \pm 2.62$ \\
\hline $250 \mu \mathrm{g} / \mathrm{ml}$ & $96.54 \pm 3.587$ & $231.77 \pm 1.92$ & $195.84 \pm 2.18$ \\
\hline $100 \mu \mathrm{g} / \mathrm{ml}$ & $93.72 \pm 4.662$ & $124.32 \pm 1.86$ & $115.55 \pm 2.14$ \\
\hline $50 \mu \mathrm{g} / \mathrm{ml}$ & $88.58 \pm 4.424$ & $101.922 \pm 2.17$ & $106.89 \pm 2.66$ \\
\hline $10 \mu \mathrm{g} / \mathrm{ml}$ & $83.64 \pm 2.553$ & $87.54 \pm 3.24$ & $98.19 \pm 2.26$ \\
\hline
\end{tabular}

Table 5: Total antioxidant capacity (equivalent to ASA/mg of plant material)

(The phosphomolybdenum method is quantitative method to detect the antioxidant activity, expressed as the number of equivalents of ascorbic acid where acidic ethanolic date palm extract had a higher capacity than the basic ethanolic date palm extracts, followed by methanolic date palm extracts.)

Determination of the total antioxidant capacity of three different date palm extracts, based on the basis of the reduction of Mo (VI) to Mo(V). Results were expressed as equivalent to ascorbic acid (ASA)/ mg of plant material. $(n=5)$ Acidic ethanolic date palm extract had a higher capacity than the basic ethanolic date palm extracts, followed by methanolic date palm extracts. 
ethanolic extract; $\mathrm{r}^{2}=0.9596(\mathrm{p}<0.05)$ for basic ethanolic extract]. $\mathrm{IC}_{50}$ values for the inhibition of lipid peroxidation were $60.69 \mu \mathrm{g} / \mathrm{ml}$ for methanolic extract, $24.75 \mu \mathrm{g} / \mathrm{ml}$ for acidic ethanolic extract and 18.03 $\mu \mathrm{g} / \mathrm{ml}$ for basic ethanolic extract. The results suggest that consumption of date palm may afford a cytoprotective effect by lowering the lipid peroxidation level.

\section{Determination of total antioxidant capacity}

Total antioxidant capacity of $P$. betle leaf is expressed as the number of equivalents of ascorbic acid. The assay is based on the reduction of $\mathrm{Mo}(\mathrm{VI})$ to $\mathrm{Mo}(\mathrm{V})$ by the extract and subsequent formation of a green phosphate $/ \mathrm{Mo}(\mathrm{V})$ complex at acid $\mathrm{pH}$. The phosphomolybdenum method is quantitative since the antioxidant activity is expressed as the number of equivalents of ascorbic acid [15]. Acidic ethanolic extract had a higher capacity than the other two varieties. The results from various free radical-scavenging system revealed that the three date palm extract samples collected by three different methods had significant antioxidant activity. The extracts were found to have different levels of antioxidant activity in the systems tested. The antioxidant activities of the three varieties were in the order acidic ethanolic extract $>$ basic ethanolic extract $>$ methanolic extract.

\section{Total flavonoid and phenol contents}

Total flavonoid content expressed as Fisetin equivalents was 15.44 $\pm 0.872 \mathrm{mg} / \mathrm{g}$ plant material in methanolic extract, $60.96 \pm 0.996 \mathrm{mg} / \mathrm{g}$ plant material in acidic ethanolic extract and $26.07 \pm 1.26 \mathrm{mg} / \mathrm{g}$ plant material in basic ethanolic extract. Total phenolic concentration showed close correlation with the antioxidant activity, being highest in basic ethanolic extract and lowest in metabolic extract of date palm. Plant phenolics present in fruit and vegetables have received considerable attention because of their potential antioxidant activity [29]. Natural polyphenols have chain-breaking antioxidant activities and are believed to prevent many degenerative diseases, including cancer and atherosclerosis [30] (Table 6).

\section{Conclusion}

Natural products have been the favourite grounds for prospecting for potential drugs or at best, as functional food or food supplement. Although fruits and vegetables have been linked with reduction of risk of cancer, cardiovascular diseases, autoimmune diseases, and various other chronic illnesses, neither the active components nor their mechanisms of action are well established. Identification of active ingredients in dietary plants, and the cell signalling pathways they modulate, can validate their use in various diseases.

\section{Total Flavonoid and phenol content:}

\begin{tabular}{|c|c|c|}
\hline Type of samples & $\begin{array}{c}\text { Flavonoid (mg } \\
\text { Fisetin/g of extract) }\end{array}$ & $\begin{array}{c}\text { Phenol (mg gallic acid/10g of } \\
\text { extract) }\end{array}$ \\
\hline Methanolic extract & $15.44 \pm 0.872$ & $411.09 \pm 2.69$ \\
\hline Acidic ethanolic extract & $60.96 \pm 0.996$ & $1127.34 \pm 4.68$ \\
\hline Basic ethanolic extract & $26.07 \pm 1.26$ & $1158.50 \pm 6.728$ \\
\hline
\end{tabular}

Table 6: Total Flavonoid and phenol content (Though the basic ethanolic extract contain maximum phenolic contents than other two tested extracts, but the bioactive flavonoid content is highest in acidic ethanolic extracts. Methanolic date palm extract is very poor in containing phenol and flavonoids)

Total flavonoid content of the date palm extracts was determined using aluminium chloride $\left(\mathrm{AlCl}_{3}\right)$ whereas the total Phenolic content was determined using the FolinCiocalteu reagent. $(n=5)$ results were expressed as $\mathrm{mg}$ of Flavonoid contents in fisetin/g of extracts and $\mathrm{mg}$ of gallic acid/ $10 \mathrm{mg}$ of the extract, taking \pm SD. Total Flavonoid and Phenol contents show a direct corelation with the total antioxidant capacity of the tested compounds. Acidic ethanolic extract is rich in both Phenolic and Flavonoid contents, and it can be correlated to its radical scavenging activities and total antioxidant properties as the data has shown, than the other two tested extracts of date palm.
In this study, we clearly demonstrated that date palm extracts, collected by three different methods hold potent anti-oxidative properties by showing DPPH radical scavenging activities (Table 1), hydroxyl radical scavenging (Table 2), superoxide radical scavenging (Table 3), significant inhibition of lipid peroxidation (Table 4). The calculated $\mathrm{IC}_{50}$ values of these three different extracts of date palm advocated the strong anti-oxidative properties (Table 5) of these crude extracts and for this reason, we are therefore interested to evaluate the in vivo anti-inflammatory activities of these compounds in preclinical models, but before this cytotoxic and anti-inflammatory properties of these three extracts must be evaluated thoroughly.

Since components of the fruit are also known aeroallergens and food allergens, we are also currently exploring the allergenic aspects of the same in our on-going in vitro and in vivo studies in tandem with extending the abovementioned findings into their anti-inflammatory potencies [31-35].

\section{Acknowledgement}

The work embodied in the study was possible due to a grant from West Bengal department of Biotechnology to ERB (sanction no. WB DBT Sanction No. 608/ BT(Estt.)/RD-26/09 dt 29-11-2011). The grant also provided fellowship to KM. The authors acknowledge Prof. B. De for providing the extracts.

\section{References}

1. Crunkhorn $P$, Meacock SC (1971) Mediators of the inflammation induced in the rat paw by carrageenin. $\mathrm{Br} \mathrm{J}$ Pharmacol 42: 392-402.

2. Winter CA, Risley EA, Nuss GW (1962) Carrageenin-induced edema in hind paw of the rat as an assay for anti-inflammatory drugs. Proc Soc Exp Biol Med 111: 544-547.

3. Robbins, Cortran (2004) Pathologic Basis of Disease (7th ed) 47-87.

4. Harsh Mohan (2002) Inflammation and Healing. Textbook of Pathology, $6^{\text {th }}$ Edition Jaypee Publication, New Delhi, 114-121.

5. Chatpaliwar VA, Johrapurkar AA, Wanjari MM, Chakraborty RR, Kharkar VT (2002) Anti-inflammatory activity of martynia diandra glox. Indian Drugs 39: 543- 545.

6. Amann R, Schuligoi R, Lanz I, Donnerer J (1995) Histamine-induced edema in the rat paw--effect of capsaicin denervation and a CGRP receptor antagonist Eur J Pharmacol 279: 227-231.

7. Dray A (1995) Inflammatory mediators of pain. British Journal of Anesthesia 75: $125-131$

8. Whittle BA (1964) The Use of Changes in Capillary Permeability in Mice to Distinguish Between Narcotic and Nonnarcotic Alalgesics. Br J Pharmacol Chemother 22: 246-253.

9. Miles AA, Miles EM (1952) Vascular reactions to histamine, histamine-liberator and leukotaxine in the skin of guinea-pigs. J Physiol 118: 228-257.

10. Braca A, De Tommasi N, Di Bari L, Pizza C, Politi M, et al. (2001) Antioxidant principles from Bauhinia tarapotensis. J Nat Prod 64: 892-895.

11. Martinez AC, Marcelo EL, Marco AO, Moacyr M (2001) Differential responses of superoxide dismutase in freezing resistant Solanum curtibolum and freezing sensitive Solanum tuberosum subjected to oxidative and water stress. Plant Science 160: 505-515.

12. Beauchamp C, Fridovich I (1971) Superoxide dismutase: improved assays and an assay applicable to acrylamide gels. Anal Biochem 44: 276-287.

13. Chung SK, Osawa T, Kawakishi S (1997) Hydroxyl radical scavenging effects of spices and scavengers from brown mustard (Brassica nigra). Bioscience Biotechnology and Biochemistry 61: 118-123.

14. Ruberto G, Baratta MT, Deans SG, Dorman HJ (2000) Antioxidant and antimicrobial activity of Foeniculum vulgare and Crithmum maritimum essential oils. Planta Med 66: 687-693.

15. Prieto P, Pineda M, Aguilar M (1999) Spectrophotometric quantitation of antioxidan capacity through the formation of a phosphomolybdenum complex: Specific application to the determination of vitamin E. Anal Biochem 269: 337-341. 
16. Lambeth JD (2004) NOX enzymes and the biology of reactive oxygen. Nat Rev Immunol 4: 181-189.

17. Kanayama A, Miyamoto $Y$ (2007) Apoptosis triggered by phagocytosis-related oxidative stress through FLIPS down-regulation and JNK activation. J Leukoc Biol 82: 1344-1352.

18. Morgenstern DE, Gifford MA, Li LL, Doerschuk CM, Dinauer MC (1997) Absence of respiratory burst in X-linked chronic granulomatous disease mice leads to abnormalities in both host defense and inflammatory response to Aspergillus fumigatus. J Exp Med 185: 207-218.

19. Shiloh MU, MacMicking JD, Nicholson S, Brause JE, Potter S, et al. (1999) Phenotype of mice and macrophages deficient in both phagocyte oxidase and inducible nitric oxide synthase. Immunity 10: 29-38.

20. Filippin LI, Vercelino R, Marroni NP, Xavier RM (2008) Redox signalling and the inflammatory response in rheumatoid arthritis. Clin Exp Immunol 152: 415-422.

21. Gilgun-Sherki Y, Melamed E, Offen D (2004) The role of oxidative stress in the pathogenesis of multiple sclerosis: the need for effective antioxidant therapy. $J$ Neurol 251: 261-268.

22. Chen J, Gusdon AM, Thayer TC, Mathews CE (2008) Role of increased ROS dissipation in prevention of T1D. Ann N Y AcadSci 1150: 157-166.

23. Yang Q, Kim YS, Lin Y, Lewis J, Neckers L, et al. (2006) Tumour necrosis factor receptor 1 mediates endoplasmic reticulum stress-induced activation of the MAP kinase JNK. EMBO Rep 7: 622-627.

24. Naik GH, Priyadarsini KI, Satav JG, Banavalikar MM, Sohoni DP, et al. (2003) Comparative antioxidant activity of individual herbal components used in Ayurvedic medicine. Phytochemistry 63: 97-104

25. Gutteridge MC (1984) Reactivity of hydroxyl and hydroxyl radicals discriminated by release of thiobarbituric acid-reactive material from deoxy sugars, nucleosides and benzoate. Biochemical Journal 224: 761-767.

26. Gutteridge JM (1987) Ferrous-salt-promoted damage to deoxyribose and benzoate. The increased effectiveness of hydroxyl-radical scavengers in the presence of EDTA. Biochem J 243: 709-714.
27. Ames BN (1983) Dietary carcinogens and anticarcinogens. Oxygen radicals and degenerative diseases. Science 221: 1256-1264.

28. Wiseman H, Halliwell B (1996) Damage to DNA by reactive oxygen and nitrogen species: role in inflammatory disease and progression to cancer. Biochem J 313: 17-29.

29. López-Vélez M, Martínez-Martínez F, Del Valle-Ribes C (2003) The study of phenolic compounds as natural antioxidants in wine. Crit Rev Food Sci Nutr 43: 233-244.

30. Roginsky V (2003) Chain breaking antioxidant activity of natural polyphenols as determined during the chain oxidation of methyl linoleate in Triton X-100 micelles. Arch Biochem Biophys 414: 261-270.

31. Chakraborty P, Roy I, Chatterjee S, Chanda S, Gupta-Bharracharya S (2006) Phoenix sylvestris Roxb pollen allergy: a 2-year randomized controlled trial and follow-up study of immunotherapy in patients with seasonal allergy in an agricultural area of West Bengal, India. J Investig Allergol Clin Immunol 16: 377-384.

32. Ishtiaq M, Hanif W, Khan MA, Ashraf M, Butt AM (2007) An ethnomedicina survey and documentation of important medicinal folklore food phytonims of flora of Samahni valley, (Azad Kashmir) Pakistan. Pak J Biol Sci 10: 2241-2256.

33. Singh AB, Shahi S (2008) Aeroallergens in clinical practice of allergy in IndiaARIA Asia Pacific Workshop report. Asian Pac J Allergy Immunol 26: 245-256.

34. Singh AB, Kumar $P$ (2003) Aeroallergens in clinical practice of allergy in India An overview. Ann Agric Environ Med 10: 131-136.

35. Puntel RL, Roos DH, Grotto D, Garcia SC, Nogueira CW, et al. (2007) Antioxidant properties of Krebs cycle intermediates against malonate prooxidant activity in vitro: a comparative study using the colorimetric method and HPLC analysis to determine malondialdehyde in rat brain homogenates. Life Sci 81: 51-62. 